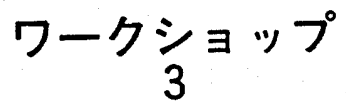

RANS モデルの拡張への取り組み

\title{
Attempts for the Extension of Turbulence Models Based on RANS \\ 正 小尾晋之介(慶大)
}

Shinnosuke OBI, Dept. Mechanical Engineering, Keio University, Yokohama 223-8522

\section{1.はじめに}

計算機の発達に伴う計算速度および記憶容量の增大、さら には複雑形状を扱うことのできる数値解析技術の進展によ って、LES が持つ工学的な重要性はますます高められてきて いる。商用 CFD コードに LES がオプションとして採用され ることがトレンドであり、近い将来、ほとんどすべての商用 コードが LESを標準装備としてゆくことだろう。一方、RANS （Reynolds Averaged Navier-Stokes）モデルは本来の適用範囲 を超えた問題をも含めて様々な場面で使い古された結果、あ まり精度の高い結果が期待できないというような印象を与 えつつある。今日までの 20 年ほどの間、商用コードの普及 と共にもてはやされた $k$-£モデルを代表とする RANS モデル は、前世紀の遺物、簡易版 CFD の代名詞、といった評価に 甘んじてしまうのだろうか。

現在の計算機環境を中心とする周辺事情は LES の適用範 囲を飛矅的に広げることに役立ってきた。しかし、計算機性 能の向上速度に基づく現実的な予測では、これまでRANS モ デルで取り扱われてきたような問題が近い将来すべて LES によって置き換えられることはないと考えられている。壁面 近傍領域のモデルや、流入境界条件の設定の煩雑さに加え、 SGS モデルの選択を誤ると、ごく単純な流れ場でも正しい結 果が得られない問題も指摘されている(1)。トレンドにまかせ て妄信的に LES の導入を進めた先に失望が待っていること は、CFD 技術の普及によって逆に $k$-£モデルの不備が明らか になったという経験から容易に推測できる。これらの状況か ら CFD ユーザが学ぶべきことは、モデルの性能についての 正しい知識を持って問題に臨む能力をユーザ自らが備える 必要があるということに尽きる。

\section{RANS モテルの拡張と LES との棲み分け}

計算速度を基準に考えれば、RANS モデルはLESに比べて 2 桁以上の優位性がある。その特長を生かし、有用なエンジ ニアリング・ツールとして有効に使うために、最近、RANS モデルを従来の枠組みから外れた問題に適用する試みが増 えてきた。その典型は、平均流そのものが強い非定常性を有 するような流れ場への適用で、例えば鈍い物体からの渦放出 を伴う流れ(2)や、ゆっくりした自然対流場 ${ }^{(3)}$ などが例として 挙げられる。RANS モデルはその名のとおり、平均化された 方程式を基礎としていることから、このような適用に際して は平均操作の物理的な解釈が本来のレイノルズの平均法と は若干異なる。そのため、まだ議論の余地は多く残されてい るが、RANS モデルの適用の拡大という点では興味深い。

一方、LES の SGS モデルの再検討を目的としてレイノル ズ応力の輸送方程式の性質を考虑する試み(4)に代表される ように、RANS モデルの考え方はLES の基礎ともなっている。 前述の点とも考え合わせれば、RANS モデルの可能性は単に 時間平均運動量式のレイノルズ応力を求めるための関係式 に留まらない。このような、RANS と LESの間を接合する概 念についてはすでに様々な解説がある(5)。

\section{3. モデルの相互評価}

RANS モデル、LES を問わず、乱流 CFD の適切な利用を実
現するためには、様々な流れ場を対象とした多角的な比較検 討を通じ、知識データベースを蓄積することが重要である。 ここではヨーロッパにおける乱流研究のグループを統括す る ERCOFTAC (European Research Community on Flow, Turbulence and Combustion)が中心となって過去 10 年以上に わたり開催してきたワークショップについて紹介する。 ERCOFTAC に設置された分科会のひとつ、Special Interest Group for Turbulence Modelling では、IAHR(International Association for Hydraulics Research)との連携で組織的なワー クショップをほほ毎年定期的に開催し、すでに 40 以上のテ ストケースについてモデルの相互評価を行っている。これら に関する情報は http://ercoftac.mech.surrey.ac.uk/に公開され ている。

図 1 および図 2 に、最近の 2 回のワークショップで取り上 げられたテストケースを示す。昨年行われた第 9 回では、(a) 燃焼器内の旋回流、(b) 滑らかな表面からのはく離流、(c) 周 期的な変動を有するはく離流、(d) 自動車を模した 3 次元物 体周りの流れ、の 4 つが取り上げられた。課題の選定に際し、 モデルの相互評価に適した物理現象を包含すること、精度の 高い実験又は DNS データがあること、数值解析技術上困難 すぎないもの、といった条件設定のほかに、なるべく参加者 の興味を引くことが考虑された。最後の点は乱流モデルに対 する工学的な要請を考えると非常に重要な点で、実際的な問 題を取り上げることで企業ユーザからの参加を促した。図 1 (d)はそのような点が最も考虑された課題であり、表 1 に示す とおり、計 18 通りの計算結果が集まった。他の 3 つのテス トケースが 2 次元であることを考慮すると、このテストケー スへの関心が高かったことが明らかである。

第 8 回と第 9 回で、それぞれのテストケースに対して提出 された結果の数を表 $1 、 2$ をもとに比較すると、第 9 回のケ 一ス 2 が 36 件、第 8 回のケース 3 が 24 件で、それぞれもっ とも参加者の関心を集めていることがわかる。これらに共通 することは、境界条件の設定が容易であること、非直交格子 による 2 次元の定常計算であること、はく離・再付着を伴う ことであり、計算を実行する際の障害の低さと、実際的なア プリケーションに近い問題であることが関心を集めること を証明している。また、いずれのケースとも、渦粘性モデル と高次モデルの差異が顕著に現れ、テストケースとしては理 想的なものとなった。

使用されるモデルに関する近年の傾向として、複雑すぎず、 かつある程度の計算結果が得られるもの、という認識が定着 しつつある、ASM（代数応力モデル）を含む非線形渦粘性モ デルが適用される例が増えてきた。第 8 回では ASM の適用 例は 2 件、非線形 $k$ - $\varepsilon$ モデルは 0 件だが、第 9 回ではそれぞ れ 3 件と 9 件であり、トレンドの変化が見える。また、RSM や $k$ を反映している。

\section{4.おわりに}

乱流モデルの性能の理解には相互比較による知識データベ 一スの積み上げが最重要である。計算技術の向上を含めて、 情報の共有が CFD の健全な発達を促すものである。 
Table 1: Referred Models in the 9th Workshop

\begin{tabular}{lcccc}
\hline Test Case & 1 & 2 & 3 & 4 \\
\hline$k-\varepsilon$ & 4 & 17 & 2 & 10 \\
NL $k-\varepsilon$ & 3 & 6 & 0 & 0 \\
$k-\omega$ & 0 & 7 & 2 & 2 \\
ASM & 3 & 0 & 0 & 0 \\
RSM & 5 & 5 & 4 & 5 \\
LES & 0 & 1 & 0 & 1 \\
Others & 0 & 0 & 2 & 0 \\
\hline Total & 15 & 36 & 8 & 18 \\
\hline
\end{tabular}

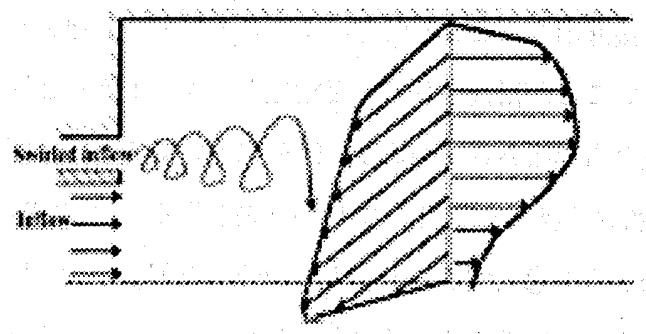

(a) Case 1. Swirling flow in a model combustor

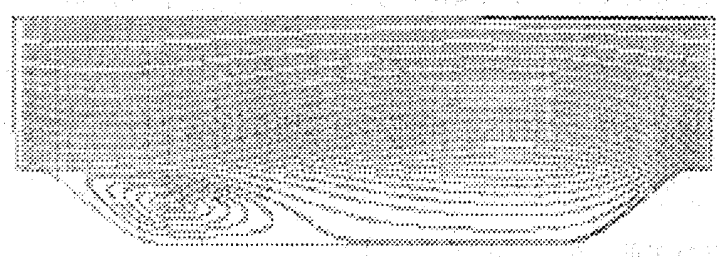

(b) Case 2. Periodic flow over a 2-D hill

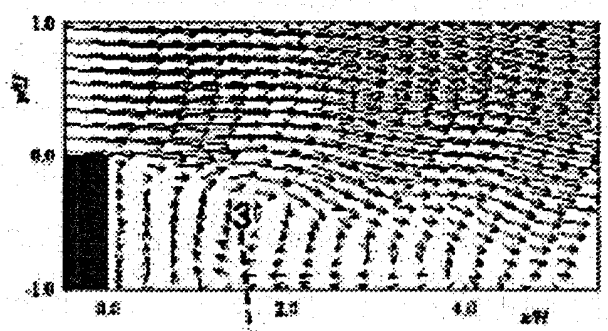

(c) Case 3. Periodically perturbed separated flow

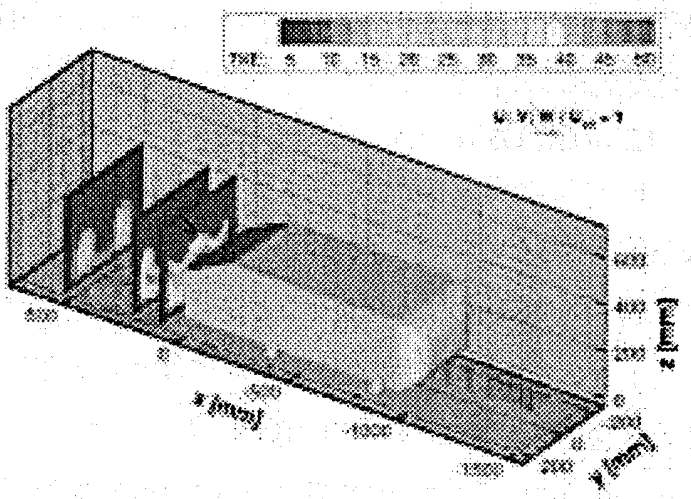

(d) Case 4. Flow around a simplified car body

Fig.1 Test cases considered for the 9th ERCOFTAC/IAHR Workshop on Refined Flow Modeling (2001).
Table 2: Referred Models in the 8th Workshop

\begin{tabular}{llll}
\hline Test Case & 1 & 2 & 3 \\
\hline$k-\varepsilon$ & 2 & 0 & 6 \\
NL $k-\epsilon$ & 0 & 0 & 0 \\
$k-\omega$ & 2 & 4 & 8 \\
ASM & 1 & 0 & 1 \\
RSM & 0 & 1 & 7 \\
LES & 2 & 0 & 2 \\
Others & 1 & 0 & 1 \\
\hline Total & 7 & 5 & 24 \\
\hline
\end{tabular}

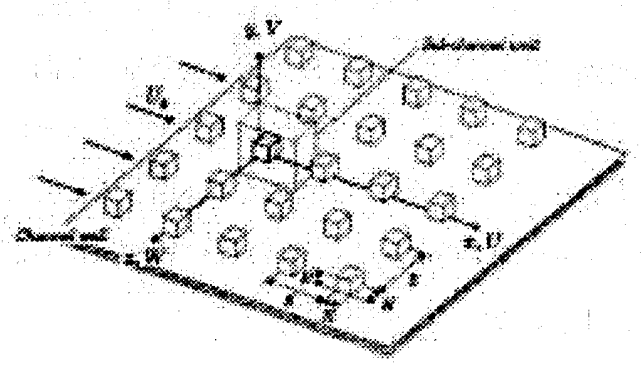

(a) Case 1. Flow in a matrix of surface-mounted cubes

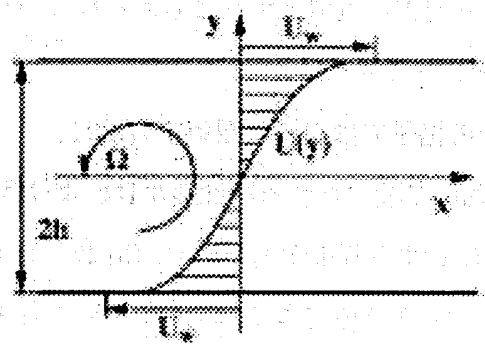

(b) Case 2. Plane turbulent Couette flow subjected to spanwise rotation with rotation numbers up to 0.5

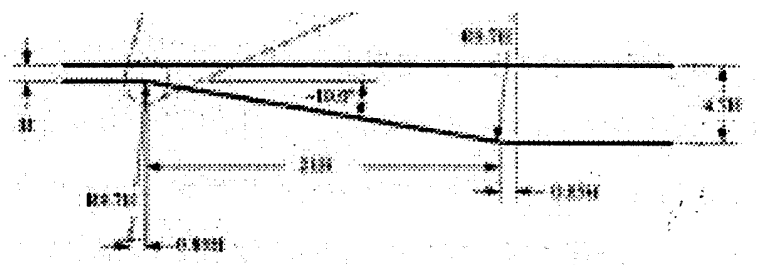

(c) Case 3. Flow through an asymmetric plane diffuser

Fig. 2 Test cases considered for the 8th ERCOFTAC/IAHR Workshop on Refined Flow Modeling (1999).

\section{参考文献}

(1) 例えば 加藤ら, 第 16 回生研 NST シンポジウム講演論 文集(2001)， P. 48.

(2) Lubcke, H. 5 , J. Winds Engineering and Industrial Aerodynamics, 89 (2001), 1471-1485.

(3) Kenjeres, S., Hanjalic, K., Int. J. Heat and. Fluid Flow, 20 (1999), $329-340$.

(4) Davidson, L., 2nd Int. Symp. Turbulence, Heat and Mass Transfer (1997), $481-490$.

(5) 例えば Spalart, P. R., Int. J. Heat and Fluid Flow, 21 (2000), $252-263$. 